\title{
PERILAKU, SIKAP DAN PENGETAHUAN KEUANGAN TERHADAP KEPUASAN KEUANGAN
}

\author{
Joshua Nathan Austin dan Nuryasman MN \\ Program Studi Manajemen Fakultas Ekonomi Universitas Tarumanagara, Jakarta \\ Email: joshua.115160396@stu.untar.ac.id;nuryasman@fe.untar.ac.id
}

\begin{abstract}
The purpose of this research is to examine the effect of financial behavior, financial attitude and financial knowledge towards financial satisfaction linkAja users. This study will examine LinkAja application users in West Jakarta as a sample. The sampling technique is done by using nonprobability sampling. The study was conducted by distributing questionnaires online using Google Form and data were processed using smart-PLS program version 3.2.2, and the respondents obtained were 210 respondents. The results of this research indicate tha financial behavior and financial knowledge have a significant effect on financial satisfaction, while financial attitude do not affect financial satisfaction.
\end{abstract}

Keywords: Financial Behavior, Financial Attitude, Financial Knowledge, Financial Satisfaction

\begin{abstract}
Abstrak: Tujuan dari penelitian ini adalah untuk meneliti pengaruh perilaku keuangan, sikap keuangan dan pengetahuan keuangan terhadap kepuasan keuangan pengguna LinkAja. Penelitian ini akan meneliti pengguna aplikasi LinkAja yang berada di Jakarta Barat sebagai sampel. Teknik pengambilan sampel dilakukan dengan menggunakan nonprobability sampling dan jenis nonprobabilty sampling yang digunakan adalah purposive sampling. Penelitian dilakukan dengan menyebarkan kuesioner secara online menggunakan bantuan google form dan data diolah menggunakan program Smart-PLS versi 3.3.2, dan responden yang diperoleh sejumlah 210 orang responden. Hasil Penelitian ini menunjukkan bahwa perilaku dan pengetahuan keuangan berpengaruh signitifkan terhadap kepuasan keuangan, sedangkan sikap keuangan tidak berpengaruh terhadap kepuasan keuangan.
\end{abstract}

Kata Kunci: Perilaku Keuangan, Sikap Keuangan, Pengetahuan Keuangan, Kepuasan Keuangan

\section{LATAR BELAKANG}

Beberapa tahun belakangan ini, perkembangan teknologi informasi berkembang semakin pesat dan memudahkan masyarakat dalam melakukan aktivitas dan kegiatan. Pada saat ini teknologi keuangan (financial technology) menjadi tren dan berkembang secara pesat yang memudahkan masyarakat masyarakat dalam mengakses produk-produk keuangan lainnya. Berdasarkan data statistik yang dikeluarkan Otoritas Jasa Keuangan (OJK) terdapat 161 perusahaan berbasis teknologi keuangan yang terdaftar di OJK periode februari 2020 (Peraturan OJK No. 77 tahun 2016). Teknologi keuangan memberikan manfaat seperti memberikan pinjaman, sebagai alat pembayaran dan penggalangan dana. Dengan kemudahan dan manfaat yang diperoleh dari penggunaan teknologi keuangan, salah satu produk yang ditawarkan adalah dompet digital seperti GOPAY, OVO, DANA, LinkAja dan sebagainya. LinkAja merupakan produk teknologi keuangan sinergi besutan himpunan bank milik negara 
(HIMBARA). Pemilihan penggunaan dompet digital tidak lepas dari kepuasan hidup yang diperoleh seseorang yang dipengaruhi faktor kesehatan, keuangan dan pendidikan. Pada penelitian ini penulis akan berfokus pada kepuasan keuangan (financial satisfaction). Kepuasan keuangan yang didapatkan tidak lepas dari pemahaman akan kondisi literasi keuangannya, namun persentase indeks literasi keuangan masyarakat masih sangat rendah yaitu sebesar $29,7 \%$.

Kepuasan keuangan pengguna LinkAja belum sepenuhnya dirasakan oleh pengguna aplikasi tersebut karena masih terdapat keluhan dan masalah pada penggunannya seperti gagal melakukan pengisian dana namun saldo terpotong, kesulitan melakukan pendaftaran dan kesulitan pembayaran. Kepuasan keuangan dipengaruhi oleh beberapa faktor yaitu pemahaman perilaku keuangan (financial behavior), sikap keuangan (financial attitude) dan memiliki pengetahuan keuangan (financial knowledge). Kepuasan keuangan menurut Sahi (2013) adalah ukuran subjektif kesejahteraan keuangan dan menunjukkan tingkat kepuasan yang dirasakan individu berkaitan dengan berbagai aspek kondisi keuangan mereka. Semakin puas seseorang dengan kondisi keuangan pribadi, maka orang tersebut juga akan semakin puas dan Bahagia. Menurut penelitian yang dilakukan Coskuner (2016) terdapat pengaruh signitifkan antara financial behavior dan financial satisfaction. Kemudian penelitian yang dilakukan Arifin (2018) menunjukkan terdapat pengaruh signitifkan antara financial attitude dan financial satisfaction. Lebih lanjut penelitian yang dilakukan Halim \& Astuti (2015) menunjukkan terdapat pengaruh yang signitifkan antara financial knowledge dan financial satisfaction. Kepuasan keuangan yang ingin didapatkan setiap orang tentunya berbeda-beda. Dengan perilaku yang dimiliki, sikap yang diambil dan pengetahuan yang dimiliki tentang keuangan, setiap orang akan mendapatkan kepuasan keuangan yang berbeda juga.

\section{KAJIAN TEORI}

Pada penelitian ini menggunakan teori planned of behavior (TPB), teori ini menjelaskan bahwa dalam melakukan sebuah perilaku seseorang harus memiliki niat, dimana niat diasumsikan sebagai faktor motivasi yang mempengaruhi perilaku yang juga sebagai indikasi seberapa keras seseorang mau mencoba dan seberapa besar upaya yang dilakukan untuk melakukan perilaku tersebut (Ajzen, 1991). Dalam TPB terdapat lima faktor yang menentukan sikap yaitu sikap, norma, keyakinan, perilaku dan kontrol perilaku yang dipersepsi. Berdasarkan teori TPB maka keterkaitain teori dengan variabel penelitian ini adalah pada penentuan sebuah perilaku yang didasari oleh niat untuk melakukan perilaku tersebut, sehingga perilaku yang dilakukan diharapkan dapat membuat seseorang merasakan kepuasan keuangan yang diharapkan. Selain perilaku yang menjadi faktor mencapai kepuasan keuangan, terdapat faktor lainnya seperti sikap keuangan dan pengetahuan keuangan.

\section{Perilaku Keuangan (Financial Behavior)}

Menurut Suryanto (2017) perilaku keuangan merupakan suatu cara yang dilakukan setiap orang untuk memperlakukan, mengelola dan menggunakan sumber keuangan yang dimilikinya. Kemudian menurut Halim dan Astuti (2015) perilaku keuangan adalah kemampuan untuk memahami, menganalisis dan mengelola keuangan untuk membuat suatu keputusan keuangan yang tepat agar terhindar dari masalah keuangan. Lebih lanjut menurut Hasibuan et al (2018) perilaku keuangan adalah seberapa baik rumah tangga atau individu mengelola sumber daya keuangan yang mencakup perencanaan anggaran tabungan, asuransi dan investasi. Dapat disimpulkan bahwa perilaku keuangan adalah sebuah perilaku yang memperlakukan, mengelola dan menggunakan keuangan yang dimiliki untuk mencapai tujuan dari penggunaan keuangan sehingga terhindar dari risiko keuangan. 


\section{Sikap Keuangan (Financial Attitude)}

Menurut Robbins dan Judge (2013), sikap ialah pernyataan evaluatif baik yang menyenangkan maupun yang tidak menyenangkan terhadap objek, individu dan peristiwa. Sikap memiliki tiga komponen utama yang terdiri dari kognitif, perasaan dan perilaku. Sedangkan menurut Arifin (2018) sikap keuangan adalah keadaan pemikiran, pendapat dan penilaian tentang keuangan. Kemudian menurut Muhidia (2019) sikap merupakan suatu cara seseorang dalam bereaksi terhadap suatu rangsangan yang akan timbul dari seseorang atau situasi. Sehingga disimpulkan sikap keuangan adalah keadaan pemikiran, pendapat dan penilaian seseorang terhadap keuangan yang dimilikinya kemudian diterapkan kedalam sikapnya sehingga dapat mempertahankan nilai tersebut dengan pengambilan keputusan dan pengelolaan yang tepat.

\section{Pengetahuan Keuangan (Financial Knowledge)}

Menurut Halim dan Astuti (2015) adalah kemampuan untuk memahami, menganalisis, dan mengelola keuangan untuk membuat suatu keputusan keuangan yang tepat agar terhindar dari masalah keuangan. Kemudian menurut Humaira dan Sagoro (2018) pengetahuan keuangan adalah sebuah penguasaan dan pengendalian seseorang atas berbagai hal tentang dunia keuangan yang terdiri dari alat keuangan (financial tools) dan ketrampilan keuangan (financial skills). Menurut Herdjiono et al (2016) pengetahuan keuangan merupakan penguasaan tentang berbagai hal mengenai keuangan, alat keuangan dan keterampilan keuangan. Maka dapat disimpulkan bahwa pengetahuan keuangan merupakan pemahaman dasar mengenai konsep dan prosedur keuangan, sehingga seseorang dapat memahami, menguasai, menganalisis dan mengelola keuangan yang tepat agar dapat terhindar dari masalah keuangan.

\section{Kepuasan Keuangan (Financial Satisfaction)}

Menurut Sahi (2013), kepuasan keuangan merupakan ukuran subjektif kesejahteraan keuangan dan menunjukkan tingkat kepuasan yang dirasakan individu berkaitan dengan berbagai aspek kondisi keuangan mereka. Kemudian menurut Chandra dan Memarista (2015) kepuasan keuangan menunjukkan tingkat kepuasan yang dirasakan oleh individu sehubungan dengan berbagai aspek situasi keuangan mereka. Kemudian menurut Ali, Rahman \& Bakar (2015) Kepuasan keuangan dapat menggambarkan level kesejahteraan yang dimiliki seseorang, semakin puas seseorang dengan kondisi keuangannya maka semakin dapat dikatakan seseorang telah memiliki kesejahteraan dalam hidupnya. Maka dapat disimpulkan bahwa kepuasan keuangan adalah sebuah ukuran subektif kesejahteraan keuangan dan menunjukkan tingkat kepuasan yang dirasakan seseorang berhubungan dengan berbagai aspek keuangan yang dimilikinya.

\section{KAITAN ANTAR VARIABEL}

\section{a. Perilaku Keuangan dengan Kepuasan Keuangan}

Penelitian yang dilakukan Coskuner (2016), Arifin (2018), Yap, Komalasari \& Hadiansah (2016), Pratiwi (2019), Darmawan (2019), Saurabh (2018) dan Halim \& Astuti (2015) menunjukkan hasil terdapat pengaruh signitifkan antara financial behavior dan financial satisfaction yang artinya semakin baik financial behavior seseorang maka tingkat kepuasan seseorang terhadap kepuasan keuangannya juga akan semakin baik. Namun berbeda dengan penelitian yang dilakukan Xiao (2015) dan Sherlyani (2020) yang menyatakan bahwa financial behavior berpengaruh negatif terhadap financial satisfaction yang artinya individu yang memiliki perilaku keuangan yang baik belum tentu menghasilkan kepuasan keuangan yang tinggi. 


\section{b. Sikap Keuangan dengan Kepuasan Keuangan}

Penelitian yang dilakukan Arifin (2018), Chandra \& Memarista (2015), Darmawan (2019), dan Santoso (2017) menunjukkan hasil terdapat pengaruh signitifkan antara financial attitude dan financial satisfaction. Maka jika seseorang memiliki financial attitude yang baik akan meningkatkan financial satisfaction orang tersebut. Berbeda dengan penelitian yang dilakukan Woodyard \& Robb (2016), Yap, Komalasari \& Hadiansah (2016) dan Armilia (2019) yang menyatakan bahwa financial attitude tidak berpengaruh terhadap financial satisfaction yang artinya seseorang yang memiliki sikap baik belum tentu memiliki kepuasan keuangan yang baik, karena memiliki sikap yang baik tidak dapat mendorong adanya kondisi keuangan yang stabil sehingga kepuasan keuangan tidak tercapai.

\section{c. Pengetahuan Keuangan dengan Kepuasan Keuangan}

Penelitian yang dilakukan oleh Halim \& Astuti (2015), Darmawan (2019) dan Saurabh (2018) menyatakan bahwa terdapat pengaruh yang signitifkan financial knowledge terhadap financial satisfaction, dimana semakin tinggi tingkat financial knowledge maka financial satisfaction yang diperoleh juga akan semakin tinggi. Namun hasil yang diperoleh berbeda dengan penelitian yang dilakukan Pratiwi (2019) yang menyatakan bahwa financial knowledge berpengaruh negatif terhadap financial satisfaction dikarenakan orang yang memiliki penegtahuan keuangan yang tinggi akan menghasilkan penilaian status keuangan yang lebih tinggi termasuk faktor-faktor negatif yang mempengaruhi kepuasan keuangan itu sendiri.

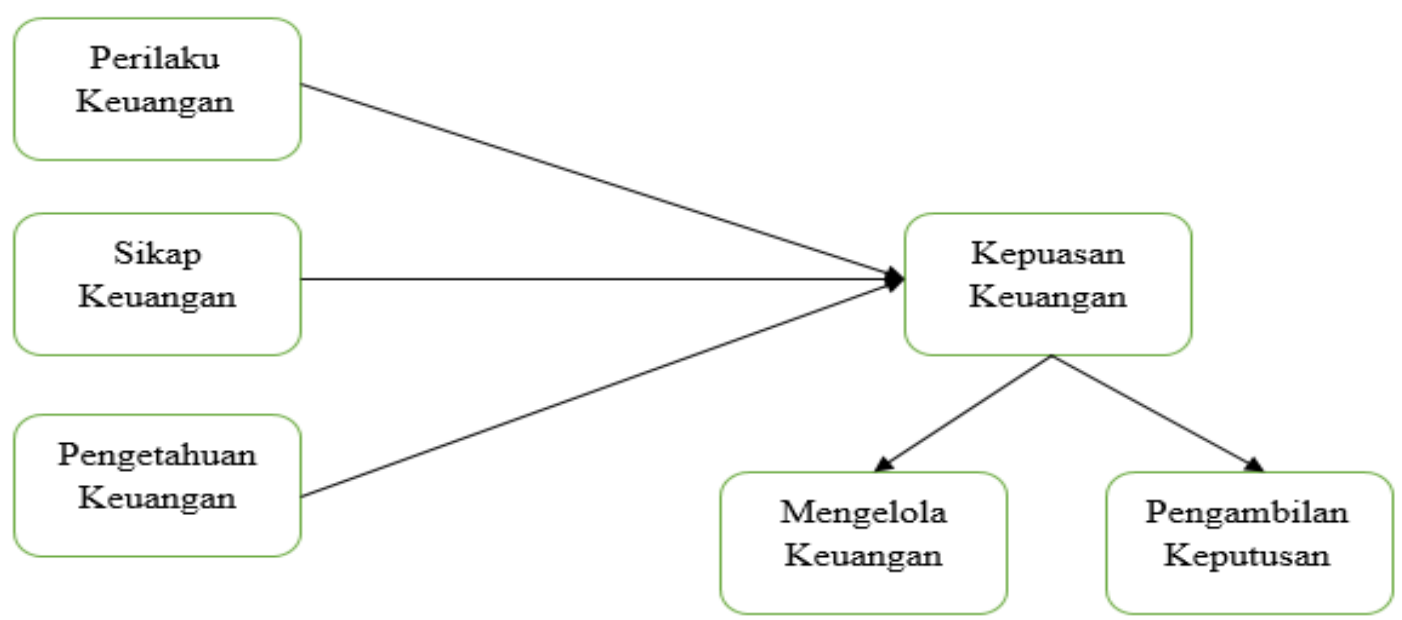

Gambar 1. Kerangka Pemikiran

Hipotesis dari model penelitian yang dibangun diatas adalah sebagai berikut:

H1: Terdapat pengaruh perilaku keuangan terhadap kepuasan keuangan pengguna LinkAja di Jakarta Barat.

$\mathrm{H} 2$ : Terdapat pengaruh sikap keuangan terhadap kepuasan keuangan pengguna LinkAja di Jakarta Barat.

H3: Terdapat pengaruh pengetahuan keuangan terhadap kepuasan keuangan pengguna LinkAja di Jakarta Barat.

\section{METODOLOGI}

Dalam penelitian ini menggunakan penelitian deskriptif yang menggunakan desain studi cross sectional. Sampel yang digunakan adalah pengguna aktif aplikasi LinkAja yang berada 
di Jakarta Barat dipilih dengan menggunakan metode nonprobabilitas sampel (nonprobabilty sampling) serta dengan menggunakan teknik pengumpulan sampel bertujuan (purposive sampling). Pengumpulan sampel dibantu dengan menggunaka Google Form yang disebarkan melalui media sosial. Teknik analisis data yang digunakan adalah structural equation modelling yang dibantu dengan aplikasi Smart-PLS versi 3.3.2. Suatu model penelitian harus memenuhi syarat uji validitas dan reliabilitasnya. Setelah sebuah model penelitian memenuhi persyaratan uji model pengukuran (outer model analysis) maka tahap selanjutnya adalah melakukan pengujian model struktural (inner model analysis) yang diuji menggunakan (a) koefisien determinasi $\left(\mathrm{R}^{2}\right)$, (b) Predictive Relevance $\left(\mathrm{Q}^{2}\right)$, (c) Effect Size $\left(\mathrm{F}^{2}\right)$, (d) Path Coefficients, (e) Uji Goodness of Fit (GoF) dan (f) uji hipotesis. Pada uji hipotesis akan dilakukan dengan melihat nilai $p$-values dan $t$-statistics.

\section{HASIL ANALISIS DATA}

Hasil uji validitas pada penelitian ini diuji dengan uji validitas konvergen (Convergent Validity). Pada uji validitas konvergen setiap indikator dinyatakan valid jika nilai AVE (Average Variance Extracted) lebih besar atau sama dengan 0,5 (Hair et al, 2014). Hasil uji validitas konvergen dapat dilihat pada tabel 1. menunjukkan hasil nilai AVE masing-masing variabel lebih besar dari 0,5 yang artinya memenuhi syarat data dapat dikatakan valid.

Tabel 1. Hasil Analisis Average Variance Extracted (AVE)

\begin{tabular}{|l|c|}
\hline & $\begin{array}{c}\text { Average Variance Extracted } \\
\text { (AVE) }\end{array}$ \\
\hline Perilaku Keuangan & 0,548 \\
\hline Sikap Keuangan & 0,517 \\
\hline Pengetahuan Keuangan & 0,601 \\
\hline Kepuasan Keuangan & 0,718 \\
\hline
\end{tabular}

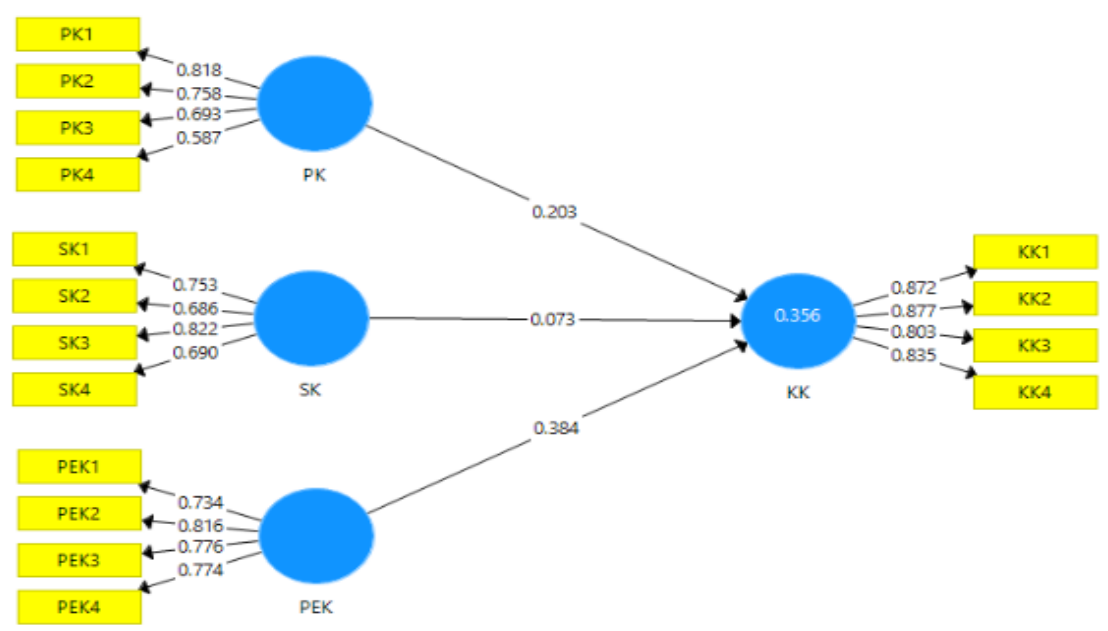

Gambar 2. Hasil Uji Validitas Konvergen

Selanjutnya dilakukan uji reabilitas terhadap variabel penelitian, suatu variabel dinyatakan reliabel jika instrumen tersebut memiliki nilai Cronbach's alpha dan Composite-Reliability 
(CR) untuk tiap variabel lebih besar dari 0,6. Nilai dari Cronbach's Alpha dan Compositer Reliabilty akan ditampilkan pada tabel 2 . dibawah ini.

Tabel 2. Hasil Uji Reabilitas

\begin{tabular}{|l|c|c|}
\hline & Cronbach's Alpha & Composite Reliability \\
\hline Kepuasan Keuangan & 0,869 & 0,910 \\
\hline Pengetahuan Keuangan & 0,781 & 0,858 \\
\hline Perilaku Keuangan & 0,682 & 0,809 \\
\hline Sikap keuangan & 0,729 & 0,828 \\
\hline
\end{tabular}

Pada tabel 2. menunjukkan nilai Cronbach's Alpha dan Composite Reliability menunjukkan angka lebih besar dari 0,6 sehingga variabel-variabel yang diteliti dapat dinyatakan reliabel.

Koefisien determinasi $\left(\mathrm{R}^{2}\right)$ dilakukan untuk mengukur dan mengetahui seberapa besar model dalam suatu penelitian dapat menjelaskan variasi dari variabel terikatnya. Pada penelitian ini nilai koefisien determinasi $\left(\mathrm{R}^{2}\right)$ menunjukkan angka 0,356, angka ini mengindikasikan bahwa variabel kepuasan keuangan dapat dijelaskan melalui variabel eksogen yaitu yaitu perilaku keuangan, sikap keuangan dan pengetahuan sebesar 35,6\% dan sisanya $64,4 \%$ dapat dijelaskan oleh variabel lainnya. Nilai koefisien determinasi yang diperoleh tergolong lemah.

Selanjutnya dilakukan pengujian predictive relvance $\left(\mathrm{Q}^{2}\right)$ yang dilakukan untuk seberapa baik nilai observasi yang dihasilkan oleh model dan juga parameternya. Hasil dari pengujian menunjukkan nilai predictive relevance yang diperoleh adalah 0,245 yang menjelaskan bahwa model dalam penelitian ini sudah memiliki predictive relevance karena nilai yang diperoleh lebih besar dari nol (0).

Pengujian selanjutnya yang dilakukan adalah uji effect size $\left(\mathrm{F}^{2}\right)$ yang dilakukan untuk mengetahui seberapa besar pengaruh yang diberikan satu variabel dengan variabel lainnya. Hasil dari pengujian akan ditampilkan pada tabel 3. dibawah ini.

Tabel 3. Hasil Uji Effect Size $\left(\mathrm{F}^{2}\right)$

\begin{tabular}{|c|c|}
\hline Variabel & Effect Size $\left(\mathrm{F}^{2}\right)$ \\
\hline Pengetahuan Keuangan & 0,112 \\
\hline Sikap Keuangan & 0,026 \\
\hline Perilaku Keuangan & 0,004 \\
\hline
\end{tabular}

Hasil yang didapat dari pengujian effect size menjelaskan bahwa efek yang diberikan pengetahuan keuangan, sikap keuangan dan perilaku keuangan adalah lemah dengan nilai masing-masing sebesar 0,112, 0,026 dan 0,004.

Tabel 4. Hasil Bootstrapping

\begin{tabular}{|c|c|c|c|}
\hline Variabel & Path & T-Statistics & P-Values \\
\hline $\begin{array}{l}\text { Perilaku Keuangan }>\text { Kepuasan } \\
\text { Keuangan }\end{array}$ & 0,203 & 2,007 & 0,045 \\
\hline $\begin{array}{l}\text { Sikap Keuangan }>\text { Kepuasan } \\
\text { keuangan }\end{array}$ & 0,073 & 0,877 & 0,381 \\
\hline
\end{tabular}




\begin{tabular}{|l|c|c|c|}
\hline $\begin{array}{l}\text { Pengetahuan Keuangan >> Kepuasan } \\
\text { Keuangan }\end{array}$ & 0,384 & 4,564 & 0,000 \\
\hline
\end{tabular}

Berdasarkan tabel 4. dapat diperoleh persamaan untuk penelitian ini adalah $\mathrm{KK}=0,203 \mathrm{PK}$ $+0,073 \mathrm{SK}+0,384 \mathrm{PEK}$. Nilai path coefficients menjelaskan bahwa variabel pengetahuan keuangan sebagai variabel dengan pengaruh terbesar untuk variabel kepuasan keuangan dengan nilai path coefficients sebesar 0,384. Kemudian perilaku keuangan dengan nilai path coefficients sebesar 0,203 dan terakhir variabel sikap keuangan sebagai variabel dengan pengaruh terkecil untuk kepuasan keuangan dengan nilai path coefficients sebesar 0,073.

Uji Goodness of Fit (GoF) dilakukan dengan tujuan untuk menyediakan pengukuran sederhana terhadap keseluruhan prediksi model dan mengevaluasi dari model pengukuran dan model struktural. Pengujian Goodness of Fit dilakukan dengan menggunakan nilai AVE dan

nilai $\mathrm{R}^{2}$ dengan rumus $\mathrm{GoF}=\sqrt{\overrightarrow{\mathrm{R}^{2}} x \overrightarrow{\mathrm{AVE}}}$, hasil yang diperoleh dari perhitungan ini adalah 0,461 dan kecocokan model penelitian ini digolongkan besar.

Pengujian Hipotesis dilakukan dengan melihat nilai $t$-statistics $>1,96$ dan $p$-values $<0,005$. Nilai t-statistics perilaku keuangan sebesar 2,007 dan nilai $p$-values sebesar 0,045 sehingga dapat disimpulkan hipotesis pertama diterima. Selanjutnya nilai $t$-statistics sikap keuangan sebesar 0,877 lebih rendah dari 1,96 dan nilai p-values sebesar 0,381 yang lebih besar dari 0,05 sehingga dapat disimpulkan hipotesis kedua ditolak dan untuk pengetahuan keuangan diperoleh nilai $t$-statistics sebesar 4,564 lebih besar dari 1,96 dan nilai $p$-values sebesar 0,000 lebih kecil dari 0,005 sehingga dapat disimpulkan hipotesis ketiga diterima.

\section{DISKUSI}

\section{Pengaruh Perilaku Keuangan terhadap Kepuasan Keuangan}

Hasil penelitian ini menunjukkan terdapat pengaruh positif perilaku keuangan terhadap kepuasan keuangan, yang dapat dibuktikan dengan melihat nilai $t$-statistics sebesar 2,007 dan nilai $p$-values yang lebih kecil dari 0,005 . Penelitian ini menggunakan empat indikator untuk mengukur variabel perilaku keuangan yaitu saya membuat anggaran pengeluaran dan belanja yang diperlukan secara rutin (PK1), saya menabung secara rutin setiap hari/minggu/bulan (PK2), saya mengetahui produk investasi seperti saham dan saya memperhatikan pergerakan harga saham (PK3) dan saya selalu membayar tagihan (listrik, air \& internet) tepat waktu (PK4). Indikator PK1 memberikan kontribusi terbesar yaitu 0,818 dikarenakan dengan membuat anggaran pengeluaran dan belanja yang diperlukan secara rutin, membuat pengeluaran keuangan menjadi teratur dan dapat meminimalisirkan pemborosan keuangan yang tidak diperlukan sehingga seseorang dapat mencapai kepuasan keuangan yang diinginkan. Sedangkan indikator PK4 memberikan kontribusi yang paling rendah yaitu sebesar 0,587, hal ini dapat disebebakan karena tidak semua orang membayar tagihan (listrik, air \& internet) secara tepat waktu, hal ini dapat terjadi karena tidak semua kondisi keuangan yang dimiliki seseorang dalam kondisi baik dan dapat membayar tagihan secara tepat waktu sehingga tingkat kepuasan keuangan yang dirasakan menjadi tidak maksimal.

Pengaruh positif mempunyai arti bahwa semakin baik perilaku keuangan yang dimiliki seseorang, maka semakin besar kepuasan keuangan yang dirasakan. Semakin baik seseorang memperlakukan, mengelola dan menggunakan keuangan yang dimiliki secara tepat untuk mencapai tujuan dari penggunaan keuangan, sehingga dapat meningkatkan kepuasan keuangan yang ingin dicapai. Indikator yang paling berpengaruh adalah saya membuat anggaran pengeluaran dan belanja yang diperlukan secara rutin. Hasil penelitian ini didukung oleh hasil penelitian yang dilakukan Coskuner (2016), Arifin (2018), Yap, Komalasari \& Hadiansah 
(2016), Pratiwi (2019), Darmawan (2019), Saurabh (2018) dan Halim \& Astuti (2015) menunjukkan hasil terdapat pengaruh signitifkan antara financial behavior dan financial satisfaction.

\section{Pengaruh Sikap Keuangan terhadap Kepuasan Keuangan}

Hasil penelitian ini menunjukkan tidak terdapat pengaruh sikap keuangan terhadap kepuasan keuangan, yang dibuktikan dengan melihat nilai $t$-statistics sebesar 0,877 dan nilai p-values lebih besar dari 0,05 yaitu 0,381. Pada penelitian ini indikator yang digunakan untuk mengukur sikap keuangan ada empat yaitu saya selalu melakukan pencatatan pendapatan dan pengeluaran sehingga tahu tujuan penggunaan keuangan saya (SK1), saya bertanggung jawab terhadap kondisi dan keamanan keuangan pribadi (SK2), saya menyusun dan memiliki perencanaan keuangan untuk masa depan saya (SK3) dan penting bagi saya untuk menetapkan target keuangan untuk 5 sampai 10 tahun kedepan untuk mencapai keberhasilan dalam keuangan (SK4). Indikator SK3 menjadi indikator yang memberikan kontribusi terbesar yaitu 0,822, dikarenakan dengan menyusun dan memiliki perencanaan keuangan untuk masa depan membuat kepuasan keuangan akan tercapai dimasa depan, sehingga kondisi keuangan orang tersebut dapat teratur dan mengurangi pengeluaran keuangan yang tidak diperlukan dan kepuasan keuangan dapat terpenuhi saat seseorang memiliki perencanaan keuangan untuk masa depannya. Sedangkan indikator SK2 menjadi indikator yang memberikan kontribusi paling rendah yaitu 0,686 , hal ini disebabkan karena tidak semua orang memiliki kesadaran untuk bertanggung jawab terhadap kondisi dan keamanan keuangan pribadinya, sehingga dengan seseorang tidak memiliki kesadaran untuk bertanggung jawab terhadap kondisi dan kemanan keuangannya akan membuat orang tersebut terkena risiko keuangan dan kepuasan keuangan yang ingin dicapai dapat menjadi tidak terpenuhi.

Pengaruh negatif mempunyai arti jika seseorang yang memiliki sikap baik belum tentu memiliki kepuasan keuangan yang baik, karena memiliki sikap yang baik tidak dapat mendorong adanya kondisi keuangan yang stabil sehingga kepuasan keuangan tidak tercapai. Indikator yang paling besar adalah saya menyusun dan memiliki perencanaan keuangan untuk masa depan saya. Hasil penelitian ini didukung oleh penelitian yang dilakukan Woodyard \& Robb (2016), Yap, Komalasari \& Hadiansah (2016) dan Armilia (2019) yang menyatakan bahwa financial attitude tidak berpengaruh terhadap financial satisfaction.

\section{Pengaruh Pengetahuan Keuangan terhadap Kepuasan Keuangan}

Hasil penelitian ini menunjukkan terdapat pengaruh positif pengetahuan keuangan terhadap kepuasan keuangan yang dibuktikan dengan nilai $t$-statistics $>1,96$ yaitu sebesar 4,564 dan nilai p-values lebih kecil dari 0,005 yaitu 0,000. Pada penelitian ini indikator yang digunakan ada empat yaitu saya mengetahui manfaat penganggaran dan perencanaan keuangan (PEK1), pengetahuan saya mengenai investasi cukup memadai dan saya tahu bagaimana saya akan menginvestasikan uang yang saya miliki (PEK2), saya mengetahui tingkat suku bunga dan biaya bunga yang dikenakan bank (PEK3) dan saya mengetahui cara terbaik untuk mengelola keuangan yang saya miliki (PEK4). Indikator PEK2 memberikan kontribusi terbesar dibandingkan indikator lainnya yaitu sebesar 0,816, karena seseorang yang memiliki pengetahuan investasi cukup memadai dan tahu bagaimana akan menginvestasikan uang yang dimiliki dapat membuat seseorang terhindar dari risiko keuangan, sehingga kepuasan keuangan yang ingin dicapai dapat terpenuhi dengan terhindar dari risiko-risiko keuangan. Sedangkan indikator PEK1 menjadi indikator yang memberikan kontribusi terendah yaitu 0,734, hal ini dapat disebabkan seseorang yang tidak mengetahui manfaat penganggaran dan perencanaan keuangan sehingga seseorang akan cenderung untuk boros terhadap keuangannya serta dapat terkena risiko keuangan, sehingga kepuasan keuangan yang dirasakan menjadi tidak maksimal. 
Arti positif ini menjelaskan bahwa semakin baik dan tinggi pengetahuan keuangan yang dimiliki seseorang, maka seseorang akan mampu mengambil keputusan, menguasai dan mengelola keuangan yang tepat sehingga dapat terhindar dari risiko masalah keuangan dan kepuasan keuangan yang diperoleh akan semakin tinggi. Indikator yang paling berpengaruh adalah pengetahuan saya mengenai investasi cukup memadai dan saya tahu bagaimana saya akan menginvestasikan uang yang saya miliki. Hasil penelitian ini sejalan dengan penelitian yang dilakukan Halim \& Astuti (2015), Darmawan (2019) dan Saurabh (2018) yang menyatakan bahwa terdapat pengaruh signitifkan financial knowledge terhadap financial satisfaction.

\section{PENUTUP}

Berdasarkan hasil dari analisis data yang ada, maka dapat disimpulkan sebagai berikut

(1) Terdapat pengaruh perilaku keuangan terhadap kepuasan keuangan pengguna LinkAja.

(2) Tidak terdapat pengaruh sikap keuangan terhadap kepuasan keuangan pengguna LinkAja.

(3) Terdapat pengaruh pengetahuan keuangan terhadap kepuasan keuangan pengguna LinkAja.

Selain itu peneliti juga menyarankan untuk menambah variabel lainnya yang mempengaruhi kepuasan keuangan seperti risk tolerance, income, financial solvency dan financial stressors. Selain itu juga agar penelitian selanjutnya untuk memperluas area dan wilayah pengambilan sampel serta menambah jumlah responden penelitian.

\section{DAFTAR PUSTAKA}

Ajzen, I. (1991). The theory of planned behavior. Organizational Behavior and Human Decission Processes, 50, 179-211. https://doi.org/10.4135/9781446249215.n22

Ali, A., Rahman, M. S. A., \& Bakar, A. (2015). Financial Satisfaction and the Influence of Financial Literacy in Malaysia. Social Indicators Research, 120(1), 137-156. https://doi.org/10.1007/s11205-014-0583-0

Arifin, A. Z. (2018). Influence Factors Toward Financial Satisfaction with Financial Behavior As Intervening Variable on Jakarta Area Workforce. European Research Studies Journal, 21(1), 90-103.

Arlinawati, M., Sawitri, N. N., \& Utomo, K. W. (2020). The Sensitivity of Financial Position and Financial Behavior of Young Workers. Vol XXIV(02), 232-249.

Armilia, N., \& Isbanah, Y. (2019). Faktor Yang Mempengaruhi Kepuasan Keuangan Pengguna Financial Technology Di Surabaya. Jurnal Ilmu Manajemen, 8(1), 39-50.

Chandra, J. W., \& Memarista, G. (2015). Faktor-Faktor yang Mempengaruhi Financial Satisfaction pada Mahasiswa Universitas Kristen Petra. Finesta, 3(2), 1-6.

Coskuner, S. (2016). Understanding Factors Affecting Financial Satisfaction: The Influence of Financial Behavior, Financial Knowledge and Demographics. Imperial Journal of Interdisciplinary Research, 2(5), 377-385.

Darmawan, D., \& Pamungkas, A. S. (2019). Pengaruh Financial Attitude, Financial Behavior, dan Financial Knowledge Terhadap Financial Satisfaction. Jurnal Manajerial Dan Kewirausahaan, I(2), 172-181.

Hair, J. F., Sarstedt, M., Hopkins, L., \& Kuppelwieser, V. G. (2014). Partial Least Squares Structural Equation Modeling (PLS-SEM): An Emerging Tool in Business Research. European Business Review, 21(1), 1-16. https://doi.org/10.1108/EBR-10-2013-0128

Halim, Y. K. E., \& Astuti, D. (2015). Financial Stressors, Financial Behavior, Risk Tolerance, 
Financial Solvency, Financial Knowledge, dan Kepuasan Finansial. Jurnal Finesta, 3(1), 19-23.

Hasibuan, B. K., Lubis, Y. M., \& HR, W. A. (2018). Financial Literacy and Financial Behavior as a Measure of Financial Satisfaction. Advances in Economics, Business and Management Research (AEBMR), 46, 503-507. https://doi.org/10.2991/ebic-17.2018.79

Herdjiono, I., Damanik, L. A., \& Musamus, U. (2016). Pengaruh Financial Attitude, Financial Knowledge, Parental Income Terhadap Financial Management. Manajemen Teori Dan Terapan, 9(3), 226-241.

Herlina, B., Hendra, W. \& Yohana. (2019). Keterkaitan Pengetahuan dan Perencanaan Keuangan Terhadap Perilaku Karyawan Pria. Jurnal Ekonomi, 24(2), 176-192. https://doi.org/10.24912/je.v24i2.567

Humaira, I., \& Sagoro, E. M. (2018). Pengaruh Pengetahuan Keuangan, Sikap Keuangan, Dan Kepribadian Terhadap Perilaku Manajemen Keuangan Pada Pelaku Umkm Sentra Kerajinan Batik Kabupaten Bantul. Jurnal Nominal, 7(1), 96-108. https://doi.org/10.21831/nominal.v7i1.19363

Komisioner, D., \& Jasa, O. (2016). Otoritas jasa keuangan republik indonesia. 1-31. https://www.ojk.go.id/id/regulasi/otoritas-jasa-keuangan/peraturanojk/Documents/Pages/POJK-Nomor-77-POJK.01-2016/SAL - POJK Fintech.pdf

Muhidia, S. C. U. (2019). Pengaruh Pengetahuan Keuangan, Sikap Keuangan dan Locus of Control terhadap Perilaku Keuangan Mahasiswa Prodi Manajemen Universitas Muhammadiyah Gresik. 58-65.

Otoritas Jasa Keuangan. (2020). Perusahaan Fintech Lending Berizin dan Terdaftar di OJK per 19 Februari 2020. 1-3. (Retrieved from: https://www.ojk.go.id/id/berita-dankegiatan/publikasi/Documents/Pages/Penyelenggara-Fintech-Terdaftar-dan-Berizin-diOJK-per-19-Februari-2020/Daftar Penyelenggara LPMUBTI 19 Feb 2020.pdf

Pangeran, P. (2016). Sikap Keuangan pada Perusahaan Keluarga: Peran Moderasi Komitmen Keluarga.Vol. XX(01), 82-101.

Pratiwi, O. (2019). Pengaruh Financial Knowledge, Financial Behavior , Financial Efficacy \& Risk Tolerance Terhadap Financial Satisfaction Pada Pegawai Pt . Bank Mandiri ( Persero ) Kantor Pusat. 1-11.

Robbins, S.P., \& Judge, T. (2013). Organizational Behavior (Seventh Ed). Pearson Education.

Sahi, S. K. (2013). Demographic and socio-economic determinants of financial satisfaction: A study of SEC-A segment of individual investors in India. International Journal of Social Economics, 40(2), 127-150. https://doi.org/10.1108/03068291311283607

Santoso, S. H. (2017). Analisis Faktor-Faktor yang Mempengaruhi Financial Satisfaction pada Masyarakat di Kota Makassar. Universitas Islam Negeri (UIN) Alauddin.

Saurabh, K., \& Nandan, T. (2018). Role of Financial Risk Attitude and Financial Behavior As Mediators in Financial Satisfaction: Empirical Evidence From India. South Asian Journal of Business Studies, 7(2), 207-224. https://doi.org/10.1108/SAJBS-07-2017-0088

Sherlyani, M., \& Pamungkas, S. (2020). Pengaruh Financial Behavior, Risk Tolerance, dan Financial Strain terhadap Financial Satisfaction. Jurnal Manajerial Dan Kewirausahaan, II(1), 272-281.

Suryanto. (2017). Pola Perilaku Keuangan Mahasiswa Di Perguruan Tinggi. Jurnal Ilmu Politik Dan Komunikasi, VII(1), 11-20.

Woodyard, A. S., \& Robb, C. A. (2016). Consideration of Financial Satisfaction: What Consumers Know, Feel and Do from a Financial Perspective. Journal of Financial Therapy, 7(2), 41-61. https://doi.org/10.4148/1944-9771.1102

Xiao, J. J., \& Porto, N. (2015). Financial Education and Financial Satisfaction: Financial Literacy, Behavior, and Capability As Mediators. International Journal of Bank 
Marketing, 35(5), 805-817. https://doi.org/10.1108/IJBM-01-2016-0009

Yap, R. J. C., Komalasari, F. \& Hadiansah, I. (2016). The Effect of Financial Literacy and Attitude on Financial Management Behavior and Satisfaction. International Journal of Administrative Science \& Organization, 23(3), 140-146. 